\title{
Penegakan Hukum Cyber Crime Dalam Upaya Penanggulangan Tindak Pidana Teknologi Informasi
}

\author{
Musa Darwin Pane, ${ }^{1}$ Sahat Maruli Tua Situmeang ${ }^{2}$ \\ ${ }^{\mathrm{a}, \mathrm{b}}$ Fakultas Hukum Universitas Komputer (UNIKOM) Bandung* \\ musa@email.unikom.ac.id; sahat@email.unikom.ac.id \\ *musa@email.unikom.ac.id
}

Naskah diterima: 16 agustus 2021, direvisi: 28 Agustus 2021, disetujui: 25 September 2021

\begin{abstract}
Abstrak
Perkembangan teknologi informasi tidak saja memberikan manfaat tetapi juga tidak luput dari dampak negatif yang menyertainya. Dalam terjadinya tindak pidana teknologi tidak memilah siapa korbannya, tidak hanya masyarakat pada umumnya tetapi dapat juga terjadi kepada aparatur pemerintahan. Dimana pada akhirnya korban mengalami kerugian. Hal tersebut terjadi dengan berbagai macam modus, berangkat dari permasalahan tersebut, maka tujuan pengabdian ini adalah untuk memberikan pemahaman terkait jenis-jenis tindak pidana teknologi informasi (cyber crime) serta bagaimana kebijakan penegakan hukum dalam upaya penanggulangan tindak pidana cyber crime. Metode yang digunakan dalam pengabdian masyarakat ini adalah memberdayakan masyarakat melalui peningkatan pengetahuan melalui edukasi. Hasil dari kegiatan adalah meningkatnya pengetahuan dan sikap hati-hati bagi masyarakat Desa Cilame Kabupaten Bandung Barat. Berdasarkan hal tersebut maka penulis berpandangan bahwa perlunya suatu lembaga bantuan hukum yang ditempatkan di setiap Kantor Kepala Desa dalam membantu menyelesaikan masalah hukum terjadinya tindak pidana teknologi informasi (cyber crime) di Desa Cilame Kabupaten Bandung Barat.
\end{abstract}

Kata-kata kunci: Penegakan Hukum; Tindak Pidana; Teknologi Informasi

Abstract
The development of information technology not only provides benefits but also does not escape
the negative impacts that accompany it. In the occurrence of technological crimes, it does not
sort out who the victims are, not only the community in general but can also occur to
government officials. Where in the end the victim suffered a loss. This happens with various
modes, departing from these problems, the purpose of this service is to provide an
understanding of the types of information technology crimes (cyber crime) and how law
enforcement policies are in an effort to overcome cyber crime. The method used in this
community service is to empower the community through increasing knowledge through
education. The result of the activity is an increase in knowledge and caution for the people of
Cilame Village, West Bandung Regency. Based on this, the authors are of the view that there is
a need for a legal aid institution to be placed in each Village Head's Office in helping to solve
legal problems in the occurrence of information technology crimes (cyber crime) in Cilame
Village, West Bandung Regency.

Keywords: Law enforcement; Criminal act; Information Technology 


\section{PENDAHULUAN}

Perkembangan teknologi dan informasi berdampak kepada semua bidang kehidupan. Dengan adanya kemajuan teknologi jarak dan waktu seolah-olah bukan lagi menjadi masalah (Ginting, 2008). Dengan kata lain bahwa teningkatan teknologi informasi bertujuan untuk mempermudah serta mempercepat pekerjaan. Manfaat tersebut dapat dirasakan apabila dikerjakan dalam ruang lingkup dan oleh oleh yang memiliki fungsi dan tugasnya serta dapat dipertanggungjawabkan. Namun, disisi lain peningkatan teknologi informasi tersebut dapat mengakibatkan kerugian dan korban apabila disalahgunakan oleh seseorang yang memanfaatkan demi mencapai tujuan demi menguntungkan dirinya sendiri, ataupun kelompoknya dengan cara yang bersifat melawan hukum.

Pelaku tindak pidana memanfaatkan media teknologi informasi untuk mencari dan memanfaatkan korbannya. Salah satu modus nya yaitu penipuan undian berhadiah yang dikirim melalui short message service (SMS) dan melalui whatsapp. Biasanya korban mendapatkan informasi kemudian diminta untuk membayar uang sebagai pembayaran pajak, administrasi dan lain-lain atas hadiah yang akan diterimanya, namun alih-alih setelah membayar sesuai arahan pelaku, korban tidak mendapatkan hadiah yang dijanjikannya. Modus lain adalah arisan online, dimana korban mengikuti arisan melalui media online setelah membayar beberapa kali pengelola tidak bisa dihubungi dan uang arisan yang telah dibayarkan oleh korban tidak dikembalikan. Ada juga korban akibat pinjaman online, dimana korban meminjam sejumlah uang kepada pengelola pinjaman dengan memberikan identitas pribadi yang kemudian bunganya sangat besar dan korban dipermalukan dan mendapatkan tekenan psikologis yang luar biasa ketika telat membayar. Selain itu ada juga yang mengalami pembelian barang secara online namun setelah korban melakukan pembayaran barang yang dibeli tersebut tidak sesuai bahkan tidak datang, dan tindak pidana siber lainnya.

Fenomena tersebut tentu sangat meresahkan masyarakat, dimana masyarakat tidak semuanya memahami akan pentingnya perlindungan data pribadi serta pentingnya kehati-hatian dalam bertransaksi melalui media online. Bahkan tidak hanya masyarakat biasa pada umumnya di daerah desa, korbannya pun ada yang berasal dari aparatur perangkat desa meskipun tidak sampai menjadi korban aparatur desa juga pernah mengalaminya. Berangkat dari permasalahan tersebut maka pentingnya edukasi kepada masyarakat Desa Cilame terkait pemahaman tentang berbagai macam tindak pidana cybercrime serta penanggulangannya. Metode yang diterapkan dalam pengabdian kepada masyarakat ini dilaksanakan dengan cara memberdayakan masyarakat melalui 
peningkatan pengetahuan melalui edukasi berupa penyuluhan hukum dan konsultasi hukum. Kegiatan pengabdian kepada masyarakat ini dilaksanakan dalam rangka meningkatkan pengetahuan dan sikap kehatihatian bagi masyarakat Desa Cilame Kabupaten Bandung Barat. Hasil penelitian menunjukan bahwa masih terdapat masyarakat yang belum memahami bahaya jejak digital dalam ruang lingkup cyber space.

\section{METODE}

Pengabdian kepada masyarakat dilakukan melalui penyuluhan hukum serta konsultasi hukum secara offline kepada masyarakat Desa dan aparatur Desa Cilame Kecamatan Ngamprah Kabupaten Bandung Barat hari Senin, 8 Maret 2021. Hasil kegiatan pengabdian kepada masyarakat ini dijelaskan dalam bentuk grafik, gambar serta foto dokumentasi sehingga memberikan gambaran sekaligus tercapainnya tujuan pengabdian kepada masyarakat.

\section{HASIL DAN PEMBAHASAN}

Berbicara mengenai perkembangan TI tentunya memberikan dampak positif juga tidak luput dari dampak negatif yang menyertainya. Dampak negatif tersebut mengakibatkan adanya korban. Sehingga keamanan masyarakat sebagai subjek sekaligus objek dari penggunaan teknologi harus memiliki sikap kehati-hatian. Hal ini mengingat bahwa kemanan masyarakat bukan saja merupakan tanggungjawab penegak hukum melainkan juga masyarakat itu sendiri (Daud, 2013). Oleh karena itu, penegakan hukum menjadi kebutuhan yang sangat penting dalam terwujudnya kepastian, keadilan dan kemanfaatan hukum disetiap penerapan hukum dalam tindak pidana teknologi informasi.

Hal ini dimaksudkan agar terciptanya ketertiban dalam masyarakat. Dimana hukum berfungsi untuk menertibkan dan mengatur masyarakat agar terciptanya lingkungan masyarakat yang aman dan tentram (Karmin, 2019). Namun disisi lain, penegakan hukum menghadapi hambatan berlatar berbagai hal yang berasal dari intern dan ekstern kemampuan penegak hukum. dari dalam diartikan sebagai kurangnya pemahaman para penegak hukum terhadap tindak pidana teknologi informasi, ketidaksiapan aparat penegak hukum dalam mencegah terjadinya tindak pidana teknologi informasi. Sedangkan kendala dari luar para penegak hukum yaitu seperti kurangnya sarana dan prasarana dalam mengungkapkan dan menanggulangi tindak pidana teknologi informasi serta kurangnya kesadaran hukum masyarakatnya terhadap tindak pidana teknologi informasi atau terhadap kejahatan cybercrime (Rahmanto, 2019). 
Padahal perlindungan hukum merupakan hal penting untuk dilakukan. "Perlindungan hukum dibagi menjadi 2 (dua), yaitu perlindungan hukum preventif dan perlindungan hukum refresif". (Dermawan \& Akmal, 2020).

Perlindungan hukum preventif dimaksudkan sebagai pengaturan tindak pidana dibidang transaksi elektronik diatur dalam hukum positif yaitu hukum yang dipakai di Indonesia, dalam hal ini tindak pidana TI diatur dalam UU ITE yang bersifat khusus atau lex specialis. Sebagaimana hal tersebut, maka kebijakan hukum terkait ketentuan pidana tindak pidana dibidang transaksi elektronik tertuang dalam "Pasal 45 hingga Pasal 52 UU ITE juncto Pasal 27 hingga Pasal 37 UU ITE terkait perbuatan yang dilarang” (Melani et al., 2020). Selain itu penyuluhan dan konsultasi hukum dalam kegiatan pengabdian masyarakat ini merupakan salah satu cara untuk meningkatkan pengetahuan masyarakat Desa Cilame yang dapat sebagai subjek sekaligus objek tindak pidana teknologi informasi (cybercrime).

\section{Gambar 1}

Penyuluhan Kepada Masyarakat Desa Cilame

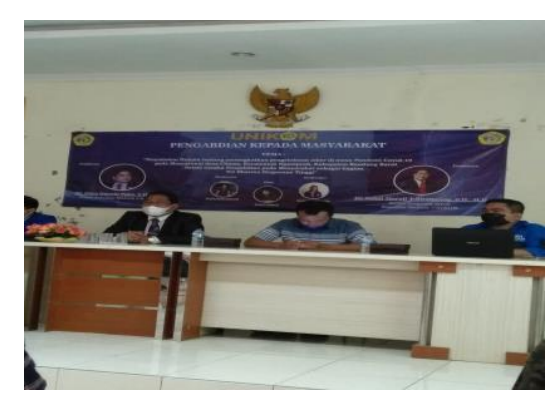

Gambar 1 menunjukan bahwa pengabdian kepada masyarakat dilakukan atas kerjasama antara Universitas Komputer Indonesia (UNIKOM) dengan Kepala Desa Cilame Kecamatan Ngamprah Kabupaten Bandung Barat, dengan tema penyuluhan hukum tentang meningkatkan pengetahuan siber di masa pandemic Covid 19 pada masyarakat Desa Cilame, Kecamatan Ngamprah Kabupaten Bandung Barat dalam rangka pengabdian kepada masyarakat sebagai bagian Tri Dharma Perguruan Tinggi. Penyuluhan hukum dalam kegiatan pengabdian kepada masyarakat ini disampaikan langsung oleh Kepala Program Studi Ilmu Hukum Fakultas Hukum Universitas Komputer Indonesia (UNIKOM) Bapak Dr. Sahat Maruli Tua Situmeang, S.H., M.H. dan oleh dosen tetap Fakultas Hukum Universitas Komputer Indonesia (UNIKOM) Bapak Dr. Musa Darwin Pane, S.H., M.H. sekaligus selaku Ahli Hukum Pidana serta acara dibuka oleh Bapak Aas Mohamad Asor, S.H. selaku Kepala Desa Cilame.

Pada kesempatan tersebut, para narasumber atau pembicara menyampaikan terkait perkembangan hukum di dunia, pengaruh hukum terhadap masyarakat, pengaruh teknologi bagi kehidupan, pengertian, jenis dan klasiikasi cybercrime, 96 
pembatasan tindak pidana cyber, fenomena kejahatan cybercrime dimasa pandemic Covid 19, motif perilaku pengguna teknologi, motif perilaku cybercrime, ancaman dan serangan cybercrime di tengah pandemi Covid 19, pembatasan cybercrime, perilaku mencegah dari cybercrime, upaya pencegahan dan penindakan cybercrime, instrument hukum nasional, cybercrime dalam undang-undang ITE, urgensi penegakan tindak pidana cybercrime. Hal ini dapat kita lihat dalam tangkapan layer materi sosialisasi sebagaimana pada gambar di bawah ini:

\section{Gambar 2}

Tangkapan Layar Maateri Sosialisasi

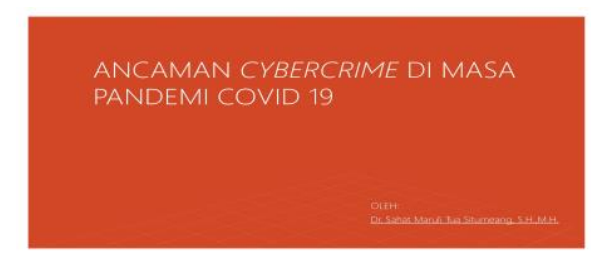

\section{APA ITU CYBERCRIME}

Cybercrime adalah istilah yang mengacu kepada aktivitas kejahatan dengan komputer atau jaringan komputer menjadi alat, sasaran atau tempat terjadinya kejanatan dunia maya cek confidence fraud, penipuan identitas, pornografi anak, dil

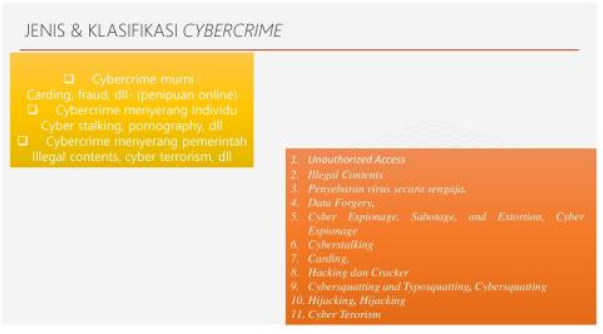

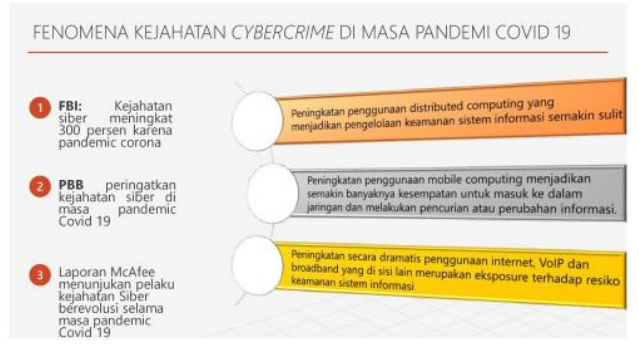
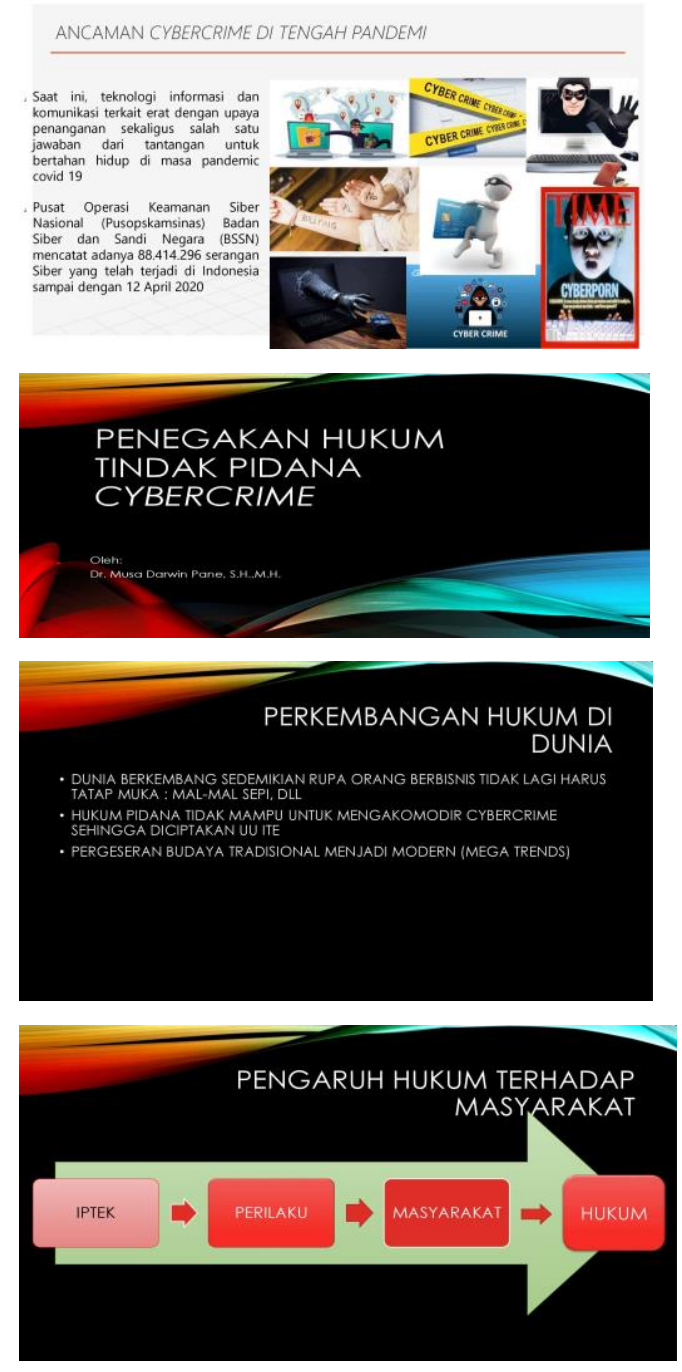

Cybercrime tidak dapat hanya dikualifikasikan dengan tindak pidana konvensional, hal ini mengingat dampak nyata yang ditimbulkannya, yang apabila hanya dilakukan pendekatan kejahatan konvensional saja maka akan banyak bentuk bentuk tindakan atau perbuatan yang tidak terakomodir oleh hukum. Sehingga, agar 
pemanfaatan teknologi informasi dapat berkembang dengan optimal dan maksimal maka harus diimbangi dengan perlindungan dan penegakan hukum yang optimal. Penegakan hukum disini tidak hanya memperhatikan pendekatan kepastian hukum melainkan juga harus memperhatikan pendekatan keadilan dan kemanfaatan hukum sebagaimana tujuan hukum itu sendiri (Koloay, 2016).

Dengan demikian dapat dipahami bahwa efektivitas hukum dapat dilihat seberapa besar ketaatan masyarakat terhadap hukum (Usman, 2015).

Perkembangan teknologi informasi mempengaruhi perilaku kehidupan masyarakat di segala bidang. Sebagai contoh berbelanja dari rumah, bekerja dari rumah dan belajar dari rumah, dimana teknologi mempermudah dalam mengakses dan mendapatkan informasi apapun (Wahyudi \& Sukmasari, 2018).

Cybercrime merupakan suaru kejahatan dengan memanfaatkan sarana teknologi informasi dengan memanfaatkan adanya celah keamanan serta ketidakhatihatian calon korban. Cybercrime diatur di dalam UU ITE (Arifah, 2011).

Adapun perbuatan yang dilarang dalam kaitannya dengan tindak pidana teknologi informasi artinya yang dilakukan dengan melawan hukum dan tanpa hak telah diatur di dalam hukum nasional, yaitu:
1) KUHP dan KUHAP

2) Undang-Undang No. 16 Tahun 2016 Tentang Informasi dan Transaksi Elektronik:

a. Pasal 27 ayat (1) melarang perbuatan yang memanfaatkan teknologi informasi yang bermuatan kesusilaan, ayat (2) yang bermuatan perjudian, ayat (3) yang bermuatan pencemaran nama baik, ayat (4) yang bermuatan pemerasan dan/atau pengancaman.

b. Pasal 28 ayat (1) "melarang perbuatan yang memanfaatkan teknologi informasi yang mengakibatkan kerugian konsumen dalam transaksi elektronik", ayat menimbulkan kebencian yang bermuatan unsur SARA.

c. Pasal 29 “melarang perbuatan yang memanfaatkan teknologi informasi yang bermuatan ancaman kekerasan atau menakutnakuti yang ditujukan secara pribadi.

d. Pasal 30 ayat (1) "melarang perbuatan yang memanfaatkan teknologi informasi untuk mengakses computer dan/atau system elektronik milik orang lain", ayat (2) “dengan tujuan 
untuk memperoleh informasi elektronik dan/atau dokumen elektronik, ayat (3) dengan cara apa pun dengan melanggar, menerobos, melampaui, atau menjebol sistem pengamanan”.

e. Pasal 31 ayat (1) "melarang intersepsi atau penyadapan atas informasi elektronik dan/atau dokumen elektronik dalam suatu komputer dan/atau sistem elektronik tertentu milik orang lain", ayat (2) "yang tidak bersifat publik dari, ke, dan di dalam suatu komputer dan/atau sistem elektronik tertentu milik orang lain, baik yang tidak menyebabkan perubahan apa pun maupun yang menyebabkan adanya perubahan".

f. Pasal 32 ayat (1) "melarang dengan cara apa pun mengubah, menambah, mengurangi, melakukan transmisi, merusak, menghilangkan, memindahkan, menyembunyikan suatu informasi elektronik dan/atau dokumen elektronik milik orang lain atau milik public”, ayat (2) “memindahkan atau mentransfer informasi elektronik dan/atau dokumen elektronik kepada sistem elektronik orang lain yang tidak berhak".

g. Pasal 33 "melarang perbuatan yang menyebabkan terganggunya sistem elektronik dan/atau mengakibatkan sistem elektronik menjadi tidak bekerja sebagaimana mestinya".

h. Pasal 34 "melarang memproduksi, menjual, mengadakan untuk digunakan, mengimpor, mendistribusikan, menyediakan, atau memiliki perangkat keras atau perangkat lunak komputer untuk memfasilitasi perbuatan sebagaimana dimaksud dalam pasal 27 sampai dengan pasal $33 "$.

i. Pasal 35 "melarang melakukan manipulasi, dengan tujuan agar informasi elektronik dan/atau dokumen elektronik tersebut dianggap seolah-olah data yang otentik",

Kebijakan pembatasan sosial berskala besar (PSBB) menyebabkan orang berada di rumah baik untuk beribadah, belajar, 99

sekolah, bekerja dan lain-lain. Oleh 
karenanya lebih banyak waktu untuk online setiap hari dan semakin mengandalkan Internet untuk mengakses layanan. Di masa pandemi covid 19 ini kejahatan dunia maya meningkat, hal ini dipicu oleh persentase populasi yang terhubung ke Internet dan waktu yang dihabiskan untuk online, dikombinasikan dengan rasa kurungan dan kecemasan dan ketakutan yang ditimbulkan pandemi covid 19, telah memberikan lebih banyak peluang bagi penjahat cyber untuk mengambil keuntungan dari situasi dan menghasilkan lebih banyak uang atau menciptakan gangguan. Teknik kejahatan dunia maya yang umum, seperti phishing, telah mengalami lonjakan. Phishing adalah praktik penipuan yang memotivasi sesorang untuk membuka identitas terkait nomor kartu kredit dan kata sandi melalui situs web atau email palsu.

Keadaan tersebut didukung dengan motif perilaku pengguna teknologi yang memandang bahwa teknologi informasi dapat digunakan dengan simple, mudah, praktis, efektif dan efisien.

Berdasarkan modusnya, cybercrime dapat digolongkan sebagai berikut (Ketaren, 2016):

\section{Unauthorized Access}

2. Illegal Contents

3. Penyebaran virus secara sengaja

4. Data Forgery
5. Cyber Espionage, Sabotage, and Extortion

6. Cyberstalking

7. Carding

8. Hacking dan Cracker

9. Cybersquatting and Typosquatting Cybersquatting

10. Hijacking

11. Infringementsof Privacy

12. Offenseagainst Intellectual Property

13. Defacing

14. Phising

15. Spamming

16. Snooping

17. Sniffing

18. Spoofing

19. Pharming

20. Malware

Kecepatan teknologi informasi yang begitu cepat membuat masyarakat cenderung lebih menerima dibandingkan menyaring terlebih dahulu kebenaran informasi yang diterima, sehingga adanya refleksi pengguna yang semakin berkurang (Noviantini et al., 2021). Oleh karena itu pencegahan melalui upaya preventif seperti penyuluhan dan sosialaisasi sangat penting untuk dilakukan dalam upaya mencegah terjadinya tindak pidana cybercrime. Selain itu upaya pencegahan dapat dilakukan dengan cara pahami program atau aplikasii yang digunakan, selalu kunci dan update security 100 
dan privacy, gunakan kata sandi atau double protection, rasional sebelum mengklik, batasi informasi yang diunggah, pahami instrument hukum nasional terkait cybercrime.

Keterkaitan antara UU ITE dengan KUHP dapat dipahami misalnya dalam ketentuan sebagaimana dimaksud dalam Pasal 362 KUHP merupakan aturan yang berkaitan dengan pencurian melalui sistem teknologi informasi. (Mewengkang, 2021).

Selain hal tersebut, Pemerintah dalam hal ini sebagai pembuat aturan hukum, harus senantiasa melibatkan berbagai stakeholders dalam masyarakat guna meningkatkan kemampuan ilmu pengetahuan di bidang Teknologi dan pembangunan infrastruktur penunjangnya. Agar dapat terwujudnya pemahaman yang baik mengenai pemanfaatan dan kegunaan akses teknologi informasi (cyber space) yang bermartabat sebagai ujung tombak media pembangunan di berbagai sektor kehidupan (Banjarnahor, 2013).

Berdasarkan hasil penelitian menunjukan bahwa masih terdapat masyarakat yang belum memahami langkah apa yang seharunya dilakukan ketika mengalami tindak pidana teknologi informasi (cybercrime). Hal ini terlihat dari beberapa pertanyaan peserta yang hadir dalam kegiatan tersebut yang mengalami sendiri atau keluarganya yang mengalami dan menanyakan terkait langkah apa yang seharunya dilakukan ketika menjadi korban kejahatan.

Dalam perjalanannya, kriminalisasi tindak pidana cyber dalam UU ITE yang mengatur penyimpangan yang terjadi pada dunia TI dan komunikasi dalam aktifitas di dunia cyber belum maksimal. Saat ini hukum internasional yang banyak digunakan negaranegara di dunia sebagai pedoman dalam pengaturan tindak pidana siber adalah Convention on Cybercrime 2001. Sehubungan dengan itu pemerintah Indonesia bermaksud untuk melakukan akses terhadap Convention on Cybercrine 2001 dan melanjutkan harmonisasi hukum nasional Indonesia dengan Convention on Cybercrime 2001.

Apabila melihat fenomena yang terjadi dimasyarakat, maka penulis berandangan diperlukannya suatu sistem yang terintegrasi dengan baik dimana melalui sistem tersebut dapat diketahui informasi yang benar atau hoax. Berbicara mengenai sistem maka seharusnya dipahami dengan bekerjanya seluruh komponen sistem dalam mencapai suatu tujuan, yang mana komponen sistem tersebut bekerja saling melengkapi. Artinya tidak hanya adanya suatu regulasi sebagai substansi hukum, adanya aparat penegak hukum, melainkan juga pentingnya peningkatan kesadaran masyarakat terhadap hukum. Penyuluhan dan konsultasi hukum 
dalam kegiatan pengabdian kepada masyarakat ini merupakan upaya dalam meningkatkan kesadaran hukum dalam masyarakat. Hal ini dapat terlihat dalam kegiatan sebagaimana dalam gambar 2 di bawah ini:

\section{Gambar 2}

Masyarakat Desa Cileme yang mendapatkan edukasi melalui penyuluhan

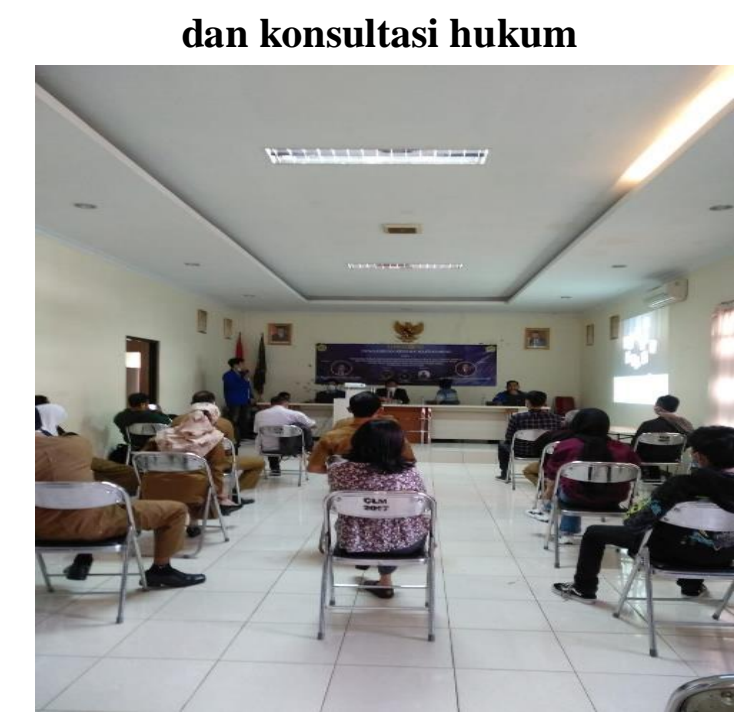

Gambar 2 menunjukan antusias masyarakat Desa Cilame Kecamatan Ngamprah Kabupaten Bandung Barat dalam kegiatan pengabdian kepada masyarakat yang diselenggarakan atas kerjasama Universitas Komputer Indonesia (UNIKOM) dengan Kepala Desa Cilame Kecamatan Ngamprah Kabupaten Bandung Barat yang pertanyaannya umumnya menanyakan terkait upaya hukum yang harus dilakukan ketika menjadi korban atau calon korban. Dimana $50 \%$ dari peserta yang hadir pernah menerima sms terkait undian berhadiah sebagai modusnya yakni penipuan, selanjutnya yang paling banyak terjadi adalah korban akibat pinjaman online.

\section{Gambar 3}

\section{Fenomena Tindak Pidana Teknologi}

Informasi Di Desa Cilame Kecamatan

\section{Ngamprah Kabupaten Bandung Barat}

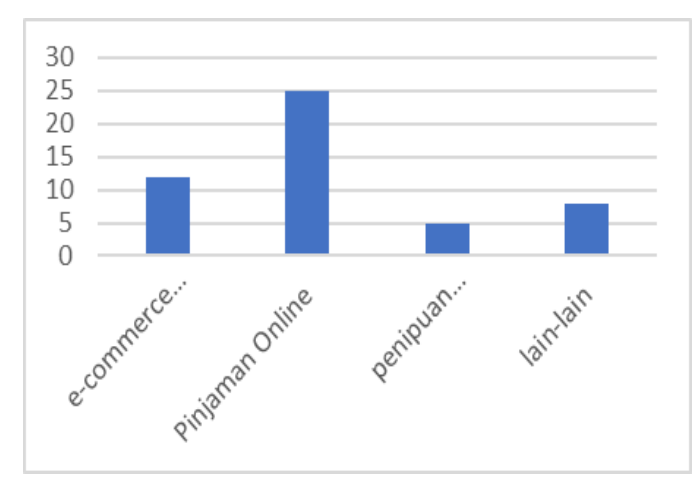

Gambar 3 menunjukan fenomena korban akibat pinjaman online lebih banyak terjadi di Desa Cilame Kecamatan Ngamprah Kabupaten Bandung Barat. Melalui penyuluhan tersebut menggambarkan adanya peningkatan pengetahuan masyarakat yang dilakukan melalui pretest dan post test selama kegiatan pengabdian kepada masyarakat berlagsung, hal tersebut dapat dilihat pada gambar di bawah ini:

\section{Gambar 4}

Pre test dan Post test Pengetahuan Masyarakat Desa Cilame Terkait Siber 


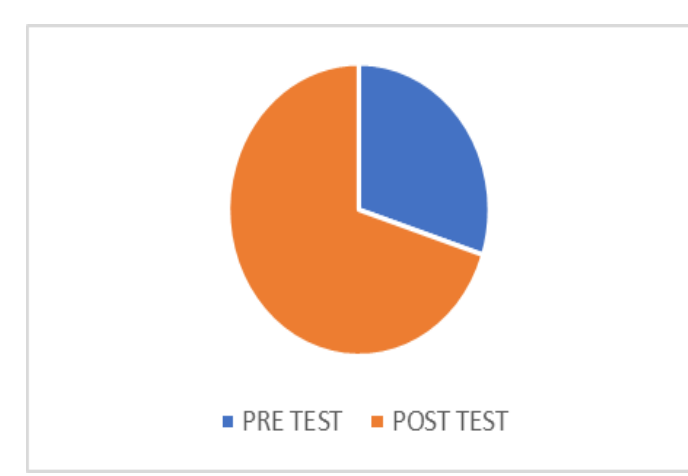

Gambar 4 menunjukan adanya peningkatan pengetahuan masyarakat Desa Cilame Kecamatan Ngamprah Kabupaten Bandung Barat dalam memahami cybercrime yang terlihat dari adanya peningkatan dari hasil post test setelah kegiatan penyuluhan hukum dilaksanakan.

Dengan dilaksanakannya kegiatan pengabdian ini harapan tim pengabdi ialah meluasnya informasi transfer ilmu pengetahuan secara makro di lingkungan masyarakat. Selain itu peran desa tidak saja melayani masyarakat desa dan membantu masyarakat desa secara administrative, mengembangkan potensi desa, mensejahterakan desa melalui berbagai kegiatan, melainkan juga memiliki tanggungjawab dalam mengedukasi masyarakatnya dalam rangka mensejahterakan masyarakat. Oleh karena itu pengabdian kepada masyarakat terkait penanggulangan tindak pidana teknologi informasi ini tidak cukup dengan melakukan sekali penyuluhan hukum melainkan harus ditindaklanjuti dengan produk hukumnya yaitu didirikannya sebuah lembaga bantuan hukum yang ditempatkan di Desa Cilame Kecamatan Ngamprah Kabupaten Bandung Barat.

\section{KESIMPULAN}

Setelah mendapatkan penyuluhan hokum kepada masyarakat Desa Cilame Kecamatan Ngamprah Kabupaten Bandung Barat, terjadi peningkatan pengetahuan dan perilaku tentang cerdas menggunakan media social. Peningkatan pengetahuan diketahui dari hasil pre test dan post test. Kenaikan nilai post test sebesar $15 \%$ dibandingkan dengan nilai pre test sebelum dilakukan penyuluhan. Diharapkan Perguruan Tinggi dapat lebih meningkatkan kegiatan pengabdian kepada masyarakat sebagai bentuk Tri Dharma Perguruan Tinggi. Selain itu diharapkan masyarakat dapat berperan aktif dalam penanganan terjadinya cybercrime. Berdasarkan hal tersebut maka penulis berpandangan bahwa perlunya suatu lembaga bantuan hukum (LBH) yang ditempatkan di setiap Kantor Kepala Desa dalam membantu menyelesaikan masalah hukum terjadinya tindak pidana teknologi informasi (cyber crime) di Desa Cilame Kabupaten Bandung Barat. Selain itu diharapkan optimalisasi peran RT dan RW sebagai sosok yang dekat dengan masyarakatnya. 


\section{UCAPAN TERIMAKASIH}

Penulis mengucapkan terima kasih kepada Kepala Desa Cilame Kecamatan Ngamprah Kabupaten Bandung Barat beserta seluruh jajarannya atas terselenggaranya kegiatan pengabdian kepada masyarakat.

\section{REFERENSI}

Arifah, D. A. (2011). Kasus cybercrime di indonesia. Jurnal Bisnis Dan Ekonomi, 18(2), 186.

Banjarnahor, J. (2013). Penegakan Cyberlaw Di Indonesia Dalam Mengatasi Cybercrime. Jurnal Ilmiah MBP, 1(1), 113.

Daud, A. (2013). Kebijakan Penegakan Hukum Dalam Upaya Penanggulangan Tindak Pidana Teknologi Informasi. Lex Crimen, 2(1), 101.

Dermawan, A., \& Akmal, A. (2020). Urgensi Perlindungan Hukum Bagi Korban Tindak Pidana Kejahatan Teknologi Informasi. Journal of Science And Social Research, 2(2), 43-44.

Ginting, P. (2008). Kebijakan Penanggulangan Tindak Pidana Teknologi Informasi Melalui Hukum Pidana. Universitas Diponegoro.

Karmin, N. I. (2019). Tindak Pidana Teknologi Informasi Dalam UndangUndang Nomor 11 Tahun 2008 Tentang Informasi Dan Transaksi Elektronik. Lex Crimen, 8(4), 46.
Ketaren, E. (2016). Cybercrime, Cyber Space, dan Cyber Law. Jurnal Times, 5(2), 37-39.

Koloay, R. N. (2016). Perkembangan Hukum Indonesia Berkenaan dengan Teknologi Informasi dan Komunikasi oleh: Renny Ns Koloay. Jurnal Hukum Unsrat, 22(5), 23.

Melani, M., Disemadi, H. S., \& Jaya, N. S. P. (2020). Kebijakan Hukum Pidana Dibidang Transaksi Elektronik Sebagai Tindak Pidana Non-Konvensional. Pandecta Research Law Journal, 15(1), 116.

Mewengkang, I. B. (2021). Kajian Yuridis Cyber Crime Penanggulangan Dan Penegakan Hukumnya. Lex Crimen, 10(5), 34 .

Noviantini, N., Remaja, I. N. G., \& Mariadi, N. N. (2021). Efektivitas Patroli Siber Dalam Mengungkap Kasus Ujaran Kebencian Di Wilayah Hukum Polres Buleleng. Kertha Widya, 9(1), 37.

Rahmanto, T. Y. (2019). Tindak Pidana Teknologi Informasi Dalam UndangUndang Nomor 11 Tahun 2008 Tentang Informasi Dan Transaksi Elektronik. De Jure, 19(1), 43-44.

Usman, A. H. (2015). Kesadaran Hukum Masyarakat Dan Pemerintah Sebagai Faktor Tegaknya Negara Hukum Di Indonesia. Jurnal Wawasan Yuridika, $30(1), 35$. 
Wahyudi, H. S., \& Sukmasari, M. P. (2018).

Teknologi dan kehidupan masyarakat.

Jurnal Analisa Sosiologi, 3(1), 20. 